U.D.C. $662.61: 662.753$

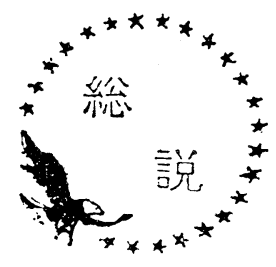

原油は軽油, 重油などに比べて安価なため, 燃料と して各種機関に使用する研究が行なわれてきた。原油 がボイラ然料として使用されたのは古く, 旧海軍が戦 略上の必要から南方原油の使用を研究して成功してい る。その後, 最近になつて電力会社がボイラに試用し 成功したので一部で実用されつつある1)。ディーゼル 機関における原油の使用は船舶技術研究所で初めて研 究され実用性が認められたので2)，これを契機として 各方面で種々の機関を使用した実験が行なわれた。ま たガスタービン燃料としての試用も，日本鋼管鶴見造 船所に打いて船舶技術研究所と共同研究され成功して いる3》。車輛用燃料としては，またわが国では実験さ れていないよらであるが，アメリカ，カナダなどにお いてはかなり大がかりな実験が行なわれ，その結果も 発表されている45)。

長所もあるが危险性が大きい原油が使用されるの は，その経済性のためであるから，まずその経済性と 安全性について述べたあと各種機関における使用の状 況について述べる。

\section{I ．原油使用の経済性}

原油の価格はその種類によつて異る上, 変動も大き いので明確ではないが, 中東現地で $9 \sim 11$ ドル $/ \mathrm{k} l$ で ある。現地の重油価格も場所によつて異なり変動もあ るが, C重油で 11 13ドル $/ \mathrm{k} l$ であるから, 油送船 に使用すれば $1 \mathrm{k} l$ 当り 2 ドル程度の燃料費が節減で きる。A重油を使用している船であればさらに数ドル の節減になる。中型油造船の燃料消費量は年間 15,000 $\sim 20,000 \mathrm{k} l$ であるから年間 $10,000 \sim 15,000$ 千円程度 の節約になる。

原油が輸入されると運賃や税金などにより高くなる が，国内の重油価格は $6,000 \sim 7,000$ 円 $/ \mathrm{k} l$ であるか ら, かなり安価である。しかし取扱いの不便, 設備の 改善などを考えると大量に使用する発電所のようなと ころでないと利益は少ない。A重油や軽油を使用する 車輛, 船舶, 陸上施設などでは, これら燃料の価格は 11, 000 13, 000 円 $/ \mathrm{k} l$ であるから然料費に著しく減少
する。カナダでの車輛実験においても経費は約 $50 \%$ に 節減されると報告されている。

\section{II. 安 全 性}

原油の燃焼性能は良好でボイラにも内燃機関にも使 用可能でめり，経済的にも有利であるにかかわらず， 実用化が遅れているのは，その危険性のためである。 原油には当然多量のガソリンが含有されているから漏 洩の危険がある。それ泫光船舶技術研究所において造 船研究協会と共同して原油の危険性の程度とその対策

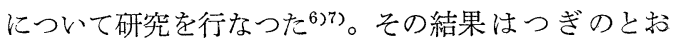
りで, その危険性は比較的小さく対策も容易であるこ とが明らかになつた。

1）一般に原油が漏洩または噴出してガスが発生す るのであるから，常に重質油を伴つているため漏洩の 発見が容易である。

2）原油の発生ガスは常に底面をはつて流れるから 検知や対策が容易である。第 1 図はガスの濃度分布の 1 例である。室内上部（床より $2.5 \mathrm{~m}$ ) より下部の平 らな油皿に原油を約 $20 \mathrm{~kg}$ 流下した場合のガス濃度分 布を示したものである。ガス濃度は爆発下限界を 100 としてあり, 引火爆発の伦険性のあるのは原油の直上 と周辺の数 $\mathrm{cm}$ のみである。なおカタル原油のガソリ ン分は約 $35 \%$ ，カフジ原油は約 $20 \%$ である。

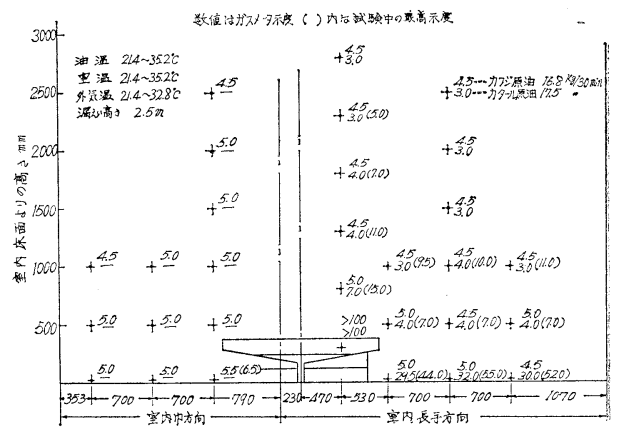

第 1 図 原油の漏えい量とガス濃度分布 
3） $5.5 \times 7.5 \times 4 \mathrm{~m}$ の室にカフジ原油約 150 。 $\mathrm{kg}$ を 漏洩させた場合でも引火爆発の危険があるのは油面 の近辺数 $\mathrm{cm}$ である。

4） $40^{\circ} \mathrm{C}$ に加熱して原油を $10 \mathrm{~mm}$ の厚さで $1 \mathrm{~m}^{2}$ に流した場合の 1 時間のガス発生量はカタル原油で約 $1 \mathrm{~kg}$ である。これを $10 \times 10 \times 5 \mathrm{~m}$ の室に均一に分布 させるとガス濃度は約 $0.14 \%$ であり, ガス検知器の 指度は 7 となる。すなおち爆発下限界の濃度の $7 / 100$ である。

5）通風预よび排気はきわめて有効な危険防止の手 段であつて，油面上の濃度すら短時間で低下させう る。第 2 図は通風開始または停止後の油面上のガス濃 度を示したもので，通風開始約 1 分後にはガス濃度は 安全範囲となり，通風停止 3 分後に法油面上は爆発下 限の濃度になる。また第 3 図は油皿上に $10 \phi$ の孔 27 個をもつた局部排気装置をおき $155 \mathrm{~m}^{2} / \mathrm{h}$ の能力で排 気した場合のガス濃度を示したものである。ガス濃度 100 以上の油面上に掠いても局部排気により容易にガ ス濃度注下する。

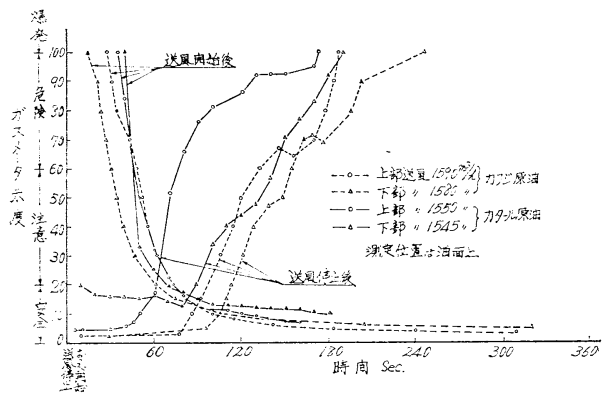

第 2 図 送風停止後および開始後の ガス濃度変化

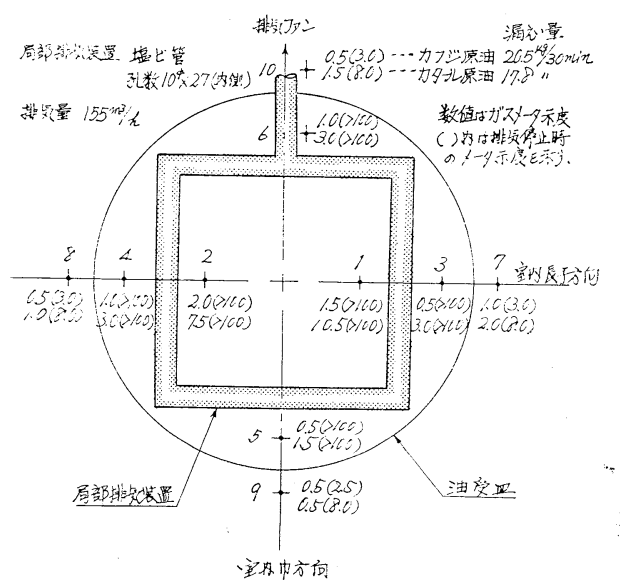

第 3 図 局部排気とガス濃度分布
6）金鋼はガスの引火防止にきわめて有効な方法で 点火源やガス抜きなどを 50 mesh 程度の金網で囲う ことにより引火を防止しうる。

7）原油の燃焼の伝播は早いが短時で普通の重油燃 焼の状態になり，20 kg 程度の原油は手持ちの小形消 火器により容易に消火しうる。

\section{III. ボイラの原油燃焼}

ボイラで原油の生だきが初めて実施されたのは昭和 18年に旧海軍の舞鶴工廠においてであつた。箨者は当 時乞の担当部員として実験計画, 実施, 成績の取纒め などを行なつた。使用したのは東南アジアの 4 種類の 原油で, 軽油分が50\%近いスマトラ原油やパラフィン 分が多く約 $20^{\circ} \mathrm{C}$ で凝固する原油などもあつた。実験 の結果は安全性の問題を除いては 2,3 の点に留意す れば容易に実用しらると決定された。安全性で最も問 題になつたのは軽油分の多いものは $25 \mathrm{~mm}$ 機銃によ る銃撃によつて発火することであつた。タンクより発 生する可燃性ガスも問題になつたが適当なガス抜き装 置によりタンクへの引火は完全に防止しらることも明 らかになつた。この他，問題としてはポンプ効率やボ イラで点火の場合着火し京かつた時の処置などであつ た。

電力業界は電力中研が工業技術院, 東京電力, 日立 製作所，新三菱重工などの協力を得て試験が行なわれ た。試験は原油の性状比較, 各種バーナによる噴霧特 性, 流量特性および燃焼特性などであつた。その結果 ボイラに原油を使用することは設備に充分な考慮を払 えば問題はなく，重油使用の場合と大差なく使用でき ると述べている。その後東京電力鶴見火力発電所の第 11 号ボイラ (蒸発管 $130 \mathrm{t} / \mathrm{h}$ ) でアラビア原油とデュ リ原油の燃焼試験が行なわれた。結果は「C重油の燃 焼装置をそのまま使用しても，原油生だきの不安定や 支障は考えられない」と発表された。さらに第 2 次試 験として長期実用試験を行ならため原油燃焼委員会を 作り東京電力，中部電力および関西電力の各発電所で 実験が行なわれた。これらの試験結果を総括するとつ ぎのとおりである。

1) 燃 焼 性

i ）火焰の長さは重油の場合より短い。

ii）炉内温度は重油より $20 \sim 30^{\circ} \mathrm{C}$ 高い。

iii）煙塺中の未燃分は少なく, 下部水管の付着物 中の炭素分も少ない。

iv）着火性はよく，直接点火ができる。

v）ボイラの熱効率は重油より若干高い。

vi）バーナは重油燃焼用の圧力噴射式および蒸気 
噴射式バーナを使用して支障ない。

2) 伝熱面の污損

i ）伝熱面の付着物量は大差ない。

ii）付着物中の死分に対するバナジウム含有率は 大差ない。

iii）今回の試験では顕著な腐食はみられない。

3) 安 全 性

i ）配管およびポンプ部から漏えい，ならびに静 電気などによる発火事故は起らなかつた。

ii）バーナ，原油ポンプおよび他の個所でガス検 知器を用いて可然性ガス濃度を測定したが，ガ スの爆発下限界を 100 とした場合，いずれも 2 を越えなかつた。
4）貯蔵中の品質変化

$172 \mathrm{k} l$ を39日間貯蔵したが，蒸気圧が若干低下

したのみで品質の変化はない。

海運界においても原油使用に関心をもち，原油中の 軽い成分を船内で分留して使用する蒸留装置や温水で 洗滌してごく軽い部分とスラッジなどを除去する水洗 装置などについて研究された ガス損失がある上装置も比較的高価で装置の安全性に も問題がある。第 1 表は引火点 $65.5^{\circ} \mathrm{C}$ をうるための 蒸留装置の性能を示したものである ${ }^{9)}$ 。水洗式は装置 は比較的簡単であるがその性能についてほ明確でない 点も多い。これら方式の研究も原油と重油の価格差の 減少と直接だきの進展によつて火になつた。

\section{第 1 表 引火点 $65.5^{\circ} \mathrm{C}$ を得るための蒸留性能試験}

\begin{tabular}{|c|c|c|c|c|}
\hline 真 & $\mathrm{mmHg}$ & \multicolumn{3}{|c|}{400} \\
\hline 原 油 種 & 類 & カタール & ワ & フ ラ \\
\hline 質 油 温 & ${ }^{\circ} \mathrm{C}$ & 190 & & 185 \\
\hline 気＼cjkstart温 & ${ }^{\circ} \mathrm{C}$ & 140 & & 135 \\
\hline 油 質 収 & wt $\%$ & 71.2 & & 88.4 \\
\hline 軽 油分収 & wt $\%$ & 22.1 & & 7.4 \\
\hline ス 発 生 & wt $\%$ & 6.7 & & 4.2 \\
\hline 回 収 & 率 wt\% & 93.3 & & 95.8 \\
\hline
\end{tabular}

\begin{tabular}{|c|c|c|c|c|c|}
\hline \multicolumn{3}{|c|}{500} & \multicolumn{3}{|c|}{600} \\
\hline カタール & ワ & フ ラ & カタール & ワ & フ ラ \\
\hline 180 & & 165 & 170 & & 145 \\
\hline 130 & & 122 & 120 & & 108 \\
\hline 72.1 & & 89.2 & 73.0 & & 89.9 \\
\hline 19.4 & & 5.7 & 16.4 & & 3.9 \\
\hline 8.5 & & 5.1 & 10.6 & & 6.2 \\
\hline 91.5 & & 94.9 & 89.4 & & 93.8 \\
\hline
\end{tabular}

直接だきは日本造船研究協会が主体となり共同研究 が行なわれ横浜造船所が実験を探当した。その結果は つぎのように結論されている。

C 重油燃焼として計画されたボイラ設備に原油苍使 用しても根本的に支障となる要素はない。バーナ型式 としては圧力噴霧式，リターンフロ一型，蒸気噴射式 のいずれも採用しうるが，原油の性状変化をお巾に考 慮しなければならないから流量特性および噴霧特性が 安定している圧力噴霧式アトマイザが最も適切であ る。燃燒性は原油の方が $\mathrm{C}$ 重油より若干勝れている点 が観察されるが特筆する程の差異はなく, 運転条件む 両者にてほとんど変らない。燃焼状況は原油の場合, 特に軽質原油ほど火炎の状況は複雑な様相を呈したが 根本的に燃焼安定性が劣ることはなく，種々な外乱要 素を与えた場合においても燃焼安定に問題はない。燃 焼特性よりくるボイラ特性への影響もC重油と同様に 取扱いらるものと考えられる。

燃焼機の特性は最終的には実機試験によつてはじめ て正確な把握がなされるものであり，腐食問題など長 期間を要する試験項目につきなお結論を導き難い点が あるが，舶用ボイラに原油を使用するのに根本的問題
ほなくほほとんど重油と同様にしかも安全に报いうる。 ことが明らかとなつた。

\section{IV. ディーゼル機関の原油状況}

\section{(1) 舶 用}

ディーゼル機関に詨する原油の生だきについては， 先に述べたごとく船研の発売を契機として，各造船所 などで盛んに研究が行なわれた。日立造船では実験用 機関 4 サイクル 40PS 機関で，新三菱神戸造船所では 3 UD 45, 1,500 PS 機関と 6 RD 90, 13,800 PS 機 関で, 三菱造船では 6 UEV 30/40, 2, 250 PS 機関で, また Sulzer Brothers Ltd. では 6RD 38，6,600 PS 機関で試験が行なわれた。

原油のように沸点範囲の広、燃料を内燃機関に使用 することにはいろいろ疑問がもたれていたが船研にお ける筆者らの研究によつて実用の可能性が明らかにな つた。実験は原油の性状が種々雑多であり，多種の原 油を入手することは容易でないことを考慮して，C重 油，A重油，灯油，無鉱ガソリンなどを混合して各種 の合成原油を作り使用した。燃焼試験においてノッキ ングなどの不具合がないことを確認した後, 実際の原 油を入手使用した。原油は中東原油中最もガソリン分 
の多いカタール原油, ガソリン分が比較的少なく粘度 の高いカフジ原油, 中間的性状で輸入の多いクエート 原油を選んだ, 試験の種類は燃燒性能試験, 腐食摩耗 試験および安全性試験で燃燒試験にはJBIA ディーゼ ル機関 (80 PS，500 r.p.m.)，腐食摩耗試験には SS 4 ディーゼル機関（4 PS，500 r.p.m.) を主として使用 した。また安全性試験には実験室の小型装置の外, 約 $40 \mathrm{~m}^{2}$ の穾験室它作り，原油の漏えい，噴出，およ び通風，局部排気，点火，消火などを行なえるよう 装置し使用した。その結果, 原油の燃焼性能はA重油 と同程度良好であり，噟食摩耗は原油の種類によつて 異なるが，同程度のイオウ分を含有したC重油よりや や多かつた。摩耗が多かつたの低イオウ分以外の含有 物の影響であるから原油より含有物の多いC重油より は良好であるら。機関運転中，付属装置における可然 性ガスの発生は少なく危険性は無かつた。第 4 困は正 味平均有効压力 $\left(p_{m e}\right)$ に対方る燃料消費率 $\left(b_{e}\right)$, 最 高圧力と玨縮圧力 $\left(p_{\text {max }}, p e\right)$, 排気温度 $\left(t_{e}\right)$ の変化 を各試験淄別に表わしたものの 1 例である。第 5 図は 各試験油の 200 時間運転におけるシリンダライナの最 大摩耗量を示したものであつて，S=1.07\%のカター

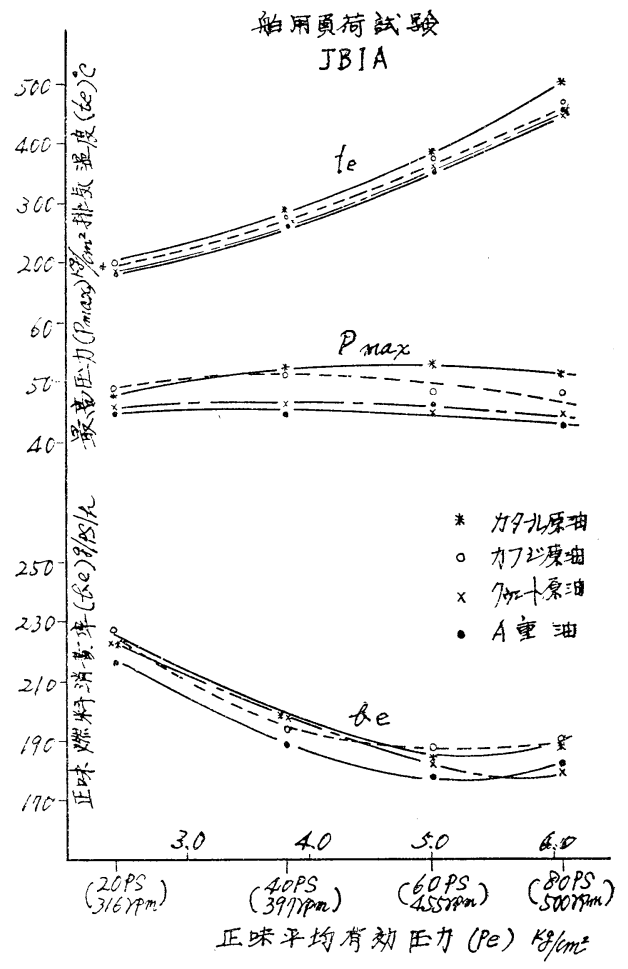

第 4 図 燃焼性能の一例

(噴射時期 $\mathrm{B}^{\mathrm{T}} \mathrm{TC} 13^{\circ}$ )
ル原油は $S=1 \%$ の A 重油と大差なく, $S=2.6 \%$ の クウエート原油は $S=3 \%$ の重油上大美ない。しか し $S=2.8 \%$ のカフジ原油は小型機関で然焼がやや悪 かつたためか $S=5 \%$ の重油程度の摩耗があつた。

船研の実験が発表されて約半年後の38 年う月に Sulzer 社で 6 RD 68 (6,600 BPS, 135 r.p.m, 6 シ リンダ，内径/ストローク 680/1, $250 \mathrm{~mm}, p_{m e} 8.08$

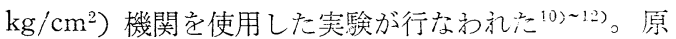
油は揮発分 (40\%) の多い Dahra の原油が便用され た。そして比較試験には粘度の低い Marime Diesel Fuel Oil が使用されている。第6 困はその試験結果 で原油とディーゼル油ではほとんど差がない。

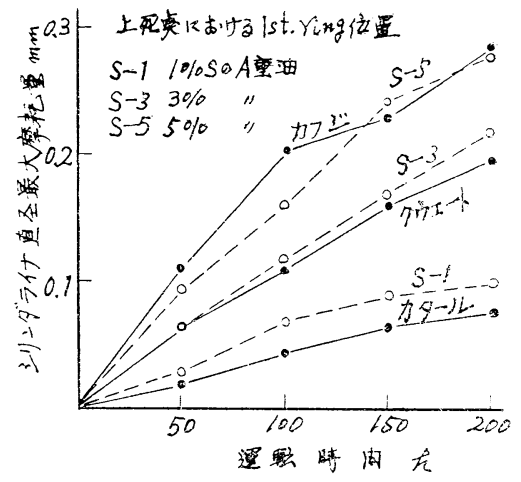

第 5 図 原油運転によるシリンダ㗫耗

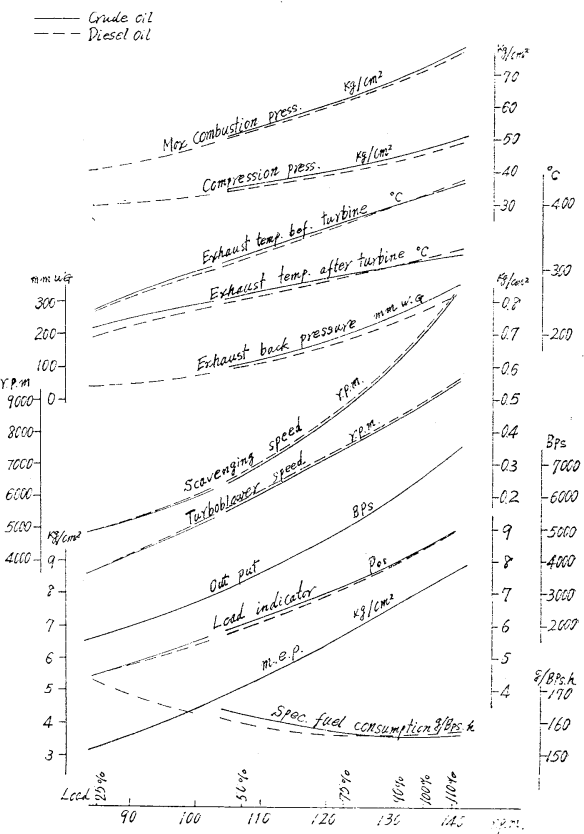

第6図 Sulzer における原油燃焼試験 


\section{第 2 表 原油の規格と試験油の性状範囲}

\begin{tabular}{llcll} 
& \multicolumn{2}{c}{ 規 } & 格 & 実用範围 \\
Specific Gravity, & $60 \mathrm{~F} / 60 \mathrm{~F}$ & less than & 0.88 & $0.82 \sim 0.851$ \\
Sulphur, & $\% \mathrm{wt}$ & $"$ & 0.5 & $0.19 \sim 0.84$ \\
Pour Point, & $\mathrm{F}$ & $"$ & 32 & $+55 \sim-65$ \\
Viscosity, & $\mathrm{SSU}$ at $100 \mathrm{~F}$ & $"$ & 60 & $35.77 \sim 53.31$ \\
Carbon Residue, & $\% \mathrm{wt}$ & " & 2.0 & $1.0 \sim 2.3$
\end{tabular}

\section{第 3 表 ヒートバランスの比較}

Equivalent of brake horsepower, (\%)

Rejected in exhaust gases,

Rejected in Cooling Water,

Friction, auxiliaries radiation,
(\%)

\begin{tabular}{|c|c|}
\hline ディーゼル油 & Texaco 原油 \\
\hline 31.4 & 30.7 \\
\hline 41.8 & 41.5 \\
\hline 13.3 & 16.2 \\
\hline 13.5 & 11.6 \\
\hline 100.0 & 100.0 \\
\hline
\end{tabular}

日本造船研究拹会第69部会で注新三菱神戸造船所が 担当し，6 RD 90 型ディーゼル機関によりカタール原 油およびワフラ原油を使用して試験された。試験は常 温と加熱時の燃焼性能試験，噴射弁噴口径の差異によ る性能比較, 燃料ポンプンランジャの間隙の影響, ピス トンリングの性能調查および安全性試験, 清浄機性能 試験などである。試験の結果はつぎのとおりで燃燒性 能はA重油と大差なく，実用しらると結論している。

i ）燃焼性能は現在の構造に何らの変更，追加する ことなく充分使用でき，従来のディーゼル燃料と 大差ない。

ii）加熱時でも燃油圧力 $2 \sim 3 \mathrm{~kg} / \mathrm{cm}^{2}$ でペーパーロ ックは起らない。

iii）機関々倸の各種部品は従来のものでも問題はな 以。

iv）安全性は然料ポンプ部にガスの漏えいが多いの でカバーを施し換気する必要はあるが，その他は ほとんど漏えいはみられず，通風のみで充分であ ると思われる。

v）清浄機は密閉形を使用して行なえば，充分原油 の使用に耐えうると思う。

(2) 車 輛用

わが国では車輛用ディーゼル機関に原油を使用する 研究はまだないようであるが，カナダ，米国などにお いては種々の研究が行なわれ，その結果の発表された ものも㐫る。車輛用ディーゼル機関には一般にディー ゼル油が使用されているから，原油の使用は経済的に は著しく有利で燃費は約 $50 \%$ に減少する。

ASME の年次大会に発表されたカナダ鉄道に执け る共同研究の結果によるとディーゼル油の代に原油を 燃料に使用すると経費注約50\%になるとしており，デ ィーゼル油との比較試験を行なつている。試験にはV V 型に気筒の機関車用エンジンを用い NRC ディーゼル

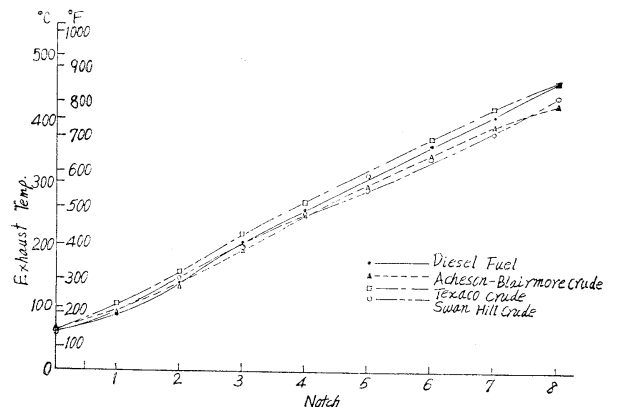

第 7 図各種燃料を使用した場合の排気ガス温度

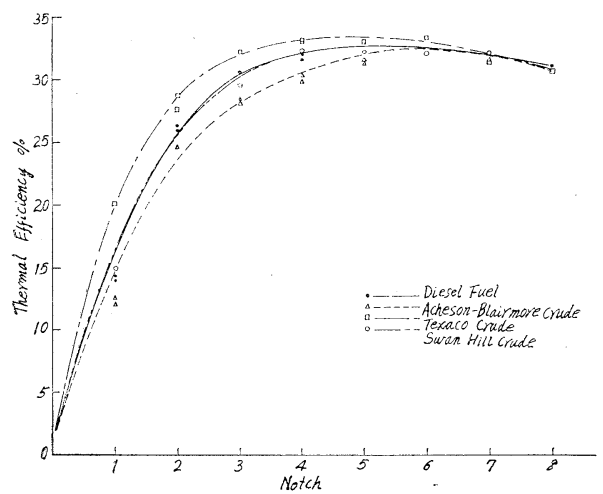

第 8 図 各種燃料を使用した場合の熱効率

工場で 1,000 時間以上の試験が行なわれた後, road test を行なつたいる。原油は第 2 表のような規格を定 め, これに適合するカナダ原油数種が使用された。実 用された原油の性状範囲を同表に示した。第7 図は各 種然料を使用した場合の排気ガス温度を示したもので 原油とディーゼル油で大差ない。また第 8 図は各種然 料の全熱受率を示したものであり, 第 3 表はディーゼ ル軽油と Texaco 原油のヒートバランを比較したもの でいずれも原油と軽油で大差ない。 


\section{V．フリーピストン機関の原油燃焼}

ボイラ，ディーゼル機関の原油だきにつづいて日本 鋼管鶴見造船所において船研と共同でフリーピストン 機関の原油だきの実験が行なわれた。第 4 表のガス発 生機にカタール, カフジおよび水洗したカフジ原油を 使用してA重油との比較試験を行なつた。

試験の結果は第 9 図に示すと打りで燃料消費率, 排 気ガス温度などは原油と $\mathrm{A}$ 重油で大差なかつた。また オッシロで記録した圧力波形を解析した結果もカフジ 原油と A重油ではほとんど差はなく, カタール原油は いくらか差がある程度であつた。

\section{第 4 表 フリーピストン機関主要目}

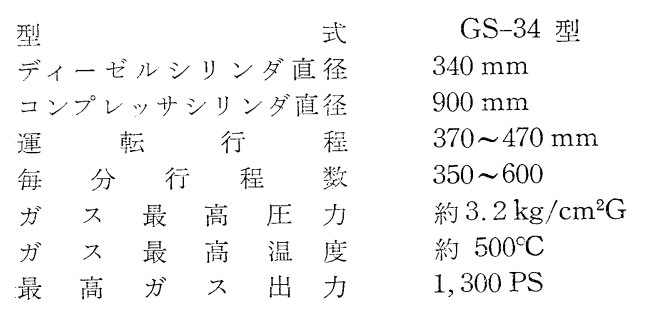

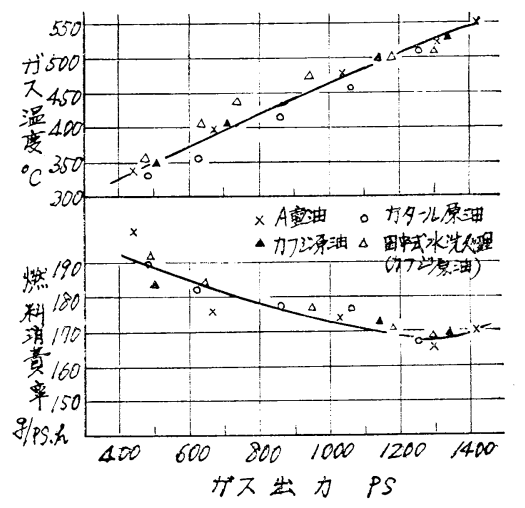

第 9 図 各原油による機関性能曲線

\section{VI. 結 語}

原油を燃料としてボイラおよび内燃機関に使用した 場合とも燃焼は重油または軽油よりむしろ良好で使用 は容易である。問題は安全性と経済性である。

原油を使用すると, 重油または軽油を使用した場合 に比べて危険性は大きくなるが，分ソリンを使用する 場合に比べると原油䨟洩の発見が容易であるから著

\section{しく安全である。}

原油の価格はC 重油に比べてやや安価であるから， その程度に応じて多量に使用する場合や入手の容易な 場合には有利である。また原油はA, B 重油や軽油に 比べると著しく安価であるからここらの燃料に替え て使用すれば著しく経済的で禹る。この場合は原油の 危険性の程度を認識して適切な対策它行なえば著しく 有利に使用することも可能であるう。

\section{文献}

1）原油燃焼試験研究会, 原油燃焼試験報告書, 37.9

2) 瀨尾, 稲見 外, 造船協会論文集, 第113号, 201 (38.6)

3) 清野, 玉木 外, 日本機械学会第 41 期講演会, (39.4)

4) H. U. Wionoishi, W. H. Cyr, C. W. Parker, ASME Publication Paper, No.62, WA 244

5) H. U. Wionoishi, J. G. Turvolgyl, A. E. Bethune, NRC Mech. Eng. Report ME-212, November (1961)

6) 日本造船研究拹会第65部会報告書 - (38年)

7) 瀨尾，稲見 外，造船協会論文集，第 115 号， 218 (39-6)

8）日本造船研究拹会第58部会報告書（37年）

9）日本造船研究協会, 高経済性油送船試設計総合報 告書, 39.3

10) The Moter Ship, July, (1963)

11) Sulzer Repost.

12) The Motor Ship Sept. (1963)

\title{
Combustion of Crude Oil
}

\author{
by Masao Seo
}

(Ship Research Institute)

SYNOPSIS :-In order to employ crude oil for boiler, diesel, gas turbine and/or rolling stock, various tests have actively been carried out, and the combustion of crude oil has been put to practical use for some fields. The utilization of crude oil chiefly depends on its lower cost as compared with heavy and light oils, although it involves a little dangerous condition. According to the test results on this condition, danger matters little and its countermeasure is very easy. 